\title{
Hegemonia e emancipação
}

Franklin Leopoldo e Silva ${ }^{4}$

Ideologia e contraideologia é um título muito significativo: mais do que designar um livro, ele designa a atitude que esse livro expressa. Pensar contra não se define como uma negação que começa e acaba em si mesma. Inclui também a positividade na forma da possibilidade. $\mathrm{E}$ esses dois elementos se reúnem quando entendemos que a positividade, incluída no pensamento de uma outra possibilidade, é alimentada pela negação, isto é, pela recusa do existente e da representação hegemônica do mundo e da história.

Uma tarefa sempre por se fazer, isto é, estamos sempre no meio do caminho: é muito tarde para desistir e voltar ao limiar, recusando a marcha, e é muito cedo para cantar vitória - para acenar com o reconhecimento de um ponto de chegada. É sintomático que o livro não traga nem introdução nem conclusão. Começa com notas de trabalho, como se o leitor pegasse o bonde andando - o trabalho em andamento - e termina com Machado de Assis, isto é, com um mundo cujos nós só desfazemos para poder (ter de) refazê-los.

Ideologia e contraideologia inclui também os significados de pró e contra. Ainda seguindo a dialética esboçada acima, devemos mencionar que a positividade da representação ideológica, no sentido do pensamento dominante, inclui o ocultamento da realidade. Neste ocultamento está a profunda concordância da ideologia com a reconstrução do real segundo alguns interesses. A representação ideológica falseia a realidade para melhor afirmá-la enquanto estabilização de interesses dominantes. Neste sentido, é pró-realidade, pró-existente. A contraideologia não produz uma representação estável da realidade, porque pretende fazer oscilar o existente na efetividade de sua firmeza, que é também a sua pretensão à verdade. A crítica da pretensão à verdade absoluta de uma perspectiva de classe é então o que dá significação ao contra de contraideologia. Não se trata de substituir uma (pretensa) verdade por outra, mas de substituir atitudes: o dogmatismo do pensamento hegemônico pela atitude crítica de recusa de uma essência do homem, do mundo e da história.

4. Franklin Leopoldo e Silva é professor titular do Departamento de Filosofia da FFLCH/USP. 
Enquanto permanece nesta atitude, a contraideologia mostra a origem relativa de todas as hegemonias. Mas, se deixa de ser processo de desestabilização da representação hegemônica e pretende a substituição de um pensamento dominante por outro, a contraideologia torna-se mecanismo produtor de ideologia. É o momento em que a contestação torna-se reposição de poder. É o momento em que o movimento contido na ideia de contra se transmuta na consolidação contida na ideia de pró. Seria preciso pensar se esta positivação representa ganho ou perda. A questão que se pode colocar aqui é que esta oposição do contraideológico ao pró-ideológico somente se sustenta se atribuirmos à contraideologia uma acepção reativa: uma atitude que apenas reage e que, portanto, não é dotada de uma autonomia que se costuma atribuir à ação e ao agir.

Mas cabe perguntar se a autonomia assim definida não acabou ficando, no decorrer da modernidade, entre as ilusões do iluminismo ou entre as ambiguidades que a filosofia mais contemporânea teria revelado. Com efeito, a liberdade, no seu exercício concreto, é inseparável dos obstáculos que deve transpor na efetividade da experiência histórica. Neste sentido, a emancipação não é nem mesmo uma ideia reguladora em sentido kantiano, pois não é algo de que nos aproximemos continuamente, mas algo de que nos aproximamos e nos afastamos, ao mesmo tempo, na ambiguidade do progresso e da regressão. A esta altura já sabemos que a razão não realiza a emancipação e pode, por vezes, produzir uma racionalização do estado de servidão como se fora emancipação.

Assim a contraideologia é trajetória de emancipação, mas repleta de riscos. Ignorá-los é perder de vista a diferença entre ideologia e contraideologia - e a negação como valor da liberdade. 